Viewpoint

\title{
The ecological sustainability trigon - A proposed conceptual framework for creating and testing management scenarios
}

\author{
J.C. Marques ${ }^{\mathrm{a}, *}$, A. Basset ${ }^{\mathrm{b}}$, T. Brey $^{\mathrm{c}}$, M. Elliott ${ }^{\mathrm{d}}$ \\ a IMAR - Institute of Marine Research, Faculty of Sciences and Technology, University of Coimbra, 3004-517 Coimbra, Portugal \\ ${ }^{\mathrm{b}}$ Department of Biological and Environmental Sciences and Technologies, University of Lecce, 73100 Lecce, Italy \\ c Alfred Wegener Institute for Polar and Marine Research, Am Alten Hafen 26, 27568 Bremerhaven, Germany \\ ${ }^{\mathrm{d}}$ Institute of Estuarine and Coastal Studies, University of Hull, Hull HU6 7RX, UK
}

\section{A R T I C L E I N F O}

\section{Keywords:}

Ecological sustainability trigon (EST)

Environmental management scenarios

Conceptual framework

\begin{abstract}
A B S T R A C T
The ability to achieve ecological sustainability and the sustainable development of marine and estuarine ecosystems constitutes a complex major challenge and depends on many driving forces, often conflicting with each other. In particular, there are three major drivers: (a) the search for human well-being, health and safety, (b) the maintenance of ecological sustainability and environmental equilibrium, and (c) the tolerance of an increasing human population pressure and demand for wealth creation.

We propose here the use of a conceptual guidance tool - the ecological sustainability trigon (EST) - as a means of building and testing environmental management scenarios. Although it requires further testing, the EST allows us to (a) address those three major drivers using human society view as a common currency, and (b) describe our behaviour, energetics (economy) and dynamics through ecological theory. Moreover, the EST appears promising for gap analysis and the means to address new research questions.

(c) 2009 Elsevier Ltd. All rights reserved.
\end{abstract}

\section{Ecological sustainability and sustainable development}

Marine environments worldwide are in severe decline, mainly as a result of over exploitation, pollution and the indirect impacts of climate change. This gives rise to an increasing awareness of the profound impact of humans on the functioning of marine ecosystems, and consequently to the need for approaches capable of sustaining those systems and where necessary restoring them (Hughes et al., 2005). General environmental concern gave rise, approximately two decades ago, to the emergence of the idea of sustainable development (Pulselli et al., 2008), but researchers from different disciplines still attempt to understand and define more precisely the meaning of the term. Despite this, the most widely adopted definition has been "development that satisfies present needs without compromising the possibility of future generations satisfying theirs" (Brundtland, 1987). This is a rather vague nonoperational definition, which implies that the concept still requires a suitable quantification in socio-economic, cultural and scientific terms (Böhringer and Jochem, 2007; Singh et al., 2009), taking into account (a) time, (b) relationships, and (c) biophysical limits (Pulselli et al., 2008).

Time is important as human society often does not evolve in accordance with the environment's capacity to produce the

\footnotetext{
* Corresponding author. Tel.: +351 239836386; fax: +351 239823603.

E-mail address: jcmimar@ci.uc.pt (J.C. Marques).
}

resources required for our development. Of course, different living and non-living natural resources are needed by society, constituting what is called natural capital. Despite the fact that sustainable development has become a key challenge for the 21st century, the way human society interacts with that natural capital is still controversial. In fact, there are two clearly opposite positions regarding the practical meaning of sustainability: weak and strong sustainability. Weak sustainability implies that well-being must be maintained over intergenerational time scales, assuming that natural capital and man-made capital are substitutes within specific production processes (Brand, 2009). As a consequence, weak sustainability accepts that the natural capital can be depleted, unless its requirement over time is declining (Brand, 2009). Conversely, strong sustainability states that natural capital and man-made capital have to be viewed as complementary. As a consequence, human society must keep each type of capital intact over time, and the whole stock of natural capital has to be preserved for present and future generations in the long run (Brand, 2009). In any case, the recognition that humans, with their cultural diversity, are an integral component of ecosystems, and the foreseeable threats represented by a serious worldwide environmental degradation have put ecological sustainability in international agendas.

Moreover, independently from the conceptual approach adopted, in cases in which uncertainties and change are key questions of environmental and social organisation, critical factors for sustainability are resilience, the capacity to cope and adapt, and 
the conservation of sources of innovation and renewal (Lebel et al., 2006). The sustainable management of natural systems may then be described as achieving a balance between delivering the economic goods and services provided by the environment, which are required for societal health and functioning, while at the same time maintaining and protecting the ecological goods and services required for natural health and functioning.

Relationships therefore become crucial as the care of environment and natural resources might be not compatible with the present economical paradigm. In fact, economic instruments often appear to lack the criterion of efficient allocation of resources, since they tend to consider only things directly linked to the market (Pulselli et al., 2008). Such relationships imply interdependencies but it is necessary to determine at what scale (regional, national, etc.) different aspects are interdependent.

Finally, biophysical limits also require to be considered as each local human population can hardly meet its needs for materials, energy, land, waste sinks and information from its own local resources. This is reflected in the concept of critical natural capital, which emerged between the "weak sustainability" and the "strong sustainability" positions, consisting of the part of the natural capital that performs important and irreplaceable environmental functions, i.e. those ecosystem services that cannot be replaced by other types of capital (De Groot et al., 2003). In fact, it is widely accepted that the maintenance of such critical natural capital is essential to environmental sustainability and sustainable development (Ekins et al., 2003) since, especially in recent centuries, societal development has been driven mostly by finite, non-renewable resources. There are at least six domains under which natural capital requires to be evaluated: socio-cultural, ecological, sustainability, ethical, economic and human survival (Brand, 2009).

Sustainable environmental management can only be achieved if a multidisciplinary approach is undertaken; management actions within that approach are required to be environmentally and ecologically sustainable, economically viable, technologically feasible, socially desirable or at least socially tolerable, administratively achievable, legally permissible and politically expedient (e.g. Elliott et al., 2006; Bunce et al., 2008; Mee et al., 2008; Ojeda-Martínez et al., 2009). Hence, as suggested above, these are the necessary requirements to achieve the main challenge for natural and social science, which is to maintain and even increase the economic goods and services required by a developing society while at the same time maintaining and protecting ecological goods and services; these together represent environmental goods and services.

The intimate linkage between the natural and social aspects of ecosystems is reflected in "The Ecosystem Approach" sensu stricto (e.g. Convention for Biological Diversity; Kay et al., 1999). In particular, there is the need for environmental restoration involving the need of dealing with problems such as: (a) losses of habitats and species diversity, as well as a decrease in habitats size and heterogeneity; (b) decrease of population size and changes in dynamics and distribution of many species; (c) habitat fragmentation and inherent increase in the vulnerability of the remaining isolated pockets; (d) decrease of economically relevant services and goods naturally provided by ecosystems (e.g. Elliott et al., 2007).

In this context, the search for ecological sustainability represents a great challenge, namely because although some ecological concepts are well understood, such as the nature of ecosystem structure and functioning, or at least properly defined, others such as resilience, carrying capacity, and ecosystem goods and services are in general still not well quantified.

At present, from the ecological point of view, the health of an ecosystem is frequently evaluated based on the abundances of few conspicuous (or even charismatic) species such as birds, fishes and marine mammals. The weakness of this approach is that mechanisms driving temporal or spatial variation in abundance are of- ten poorly known, and the consequences of changes in these species to the ecosystem as a whole are rarely considered (Hughes et al., 2005). Therefore, the application of resilience-based management, for instance, represents a novel and opportune approach to marine ecosystems, namely regarding fisheries, shifting the focus from conservation of targeted (often commercially important) species to active management of functional groups that support essential processes and sustain ecosystems services (Hughes et al., 2005). The fundamental difference is that this focus on functional groups recognises the importance of ecological roles (including the role of humans) and of species interactions for sustaining ecosystems resilience across temporal and spatial scales (Folke, 2006).

In spite of its central position in sustainability science, the resilience concept has suffered considerable changes in the last three decades (Walker et al., 2004). Recently, Elliott et al. (2007) attempted to remove the confusion regarding the term by taking the view that it referred the inherent ability of a system to return to a previous or similar state following disturbance (see Fig. 1 in Elliott et al., 2007); that paper further indicated that resistance is the ability of the system to withstand any stressor. However, at least two other meanings for it can be distinguished. The first refers to dynamics close to equilibrium and is defined as the time required for a system to return to an equilibrium point following a disturbance event, or system's recovery. It is termed engineering resilience (Holling, 1996; Folke, 2006) and is largely equivalent to the stability property elasticity (Grimm and Wissel, 1997), which can be seen as resistance to change (Levin and Lubchenco, 2008). A further meaning refers to dynamics far from any equilibrium steady state and is defined as the capacity to absorb stress and yet still maintain "function" - this has been termed ecological resilience (Gunderson and Holling, 2002; Folke, 2006), i.e. the capacity to maintain functioning despite multiple stressors which affect a developing system (Levin and Lubchenco, 2008). This is more related to renewal, regeneration, or re-organisation following disturbance than to the system's recovery (Folke, 2006). In this case, disturbance events and spatial heterogeneity cause each system's behaviour to be unique and the complexity of the system combined with unanticipated compounded effects can make recovery trajectories difficult or impossible to predict. A recovered system may look similar but it is not the same system, because like any living system it is continuously developing (Folke, 2006). Elliott et al. (2007) termed the differences in degradation and recovery trajectories as hysteresis in the system. Ecological resilience has to be estimated by means of resilience surrogates (Carpenter et al., 2005), based on a comprehensive resilience analysis, including

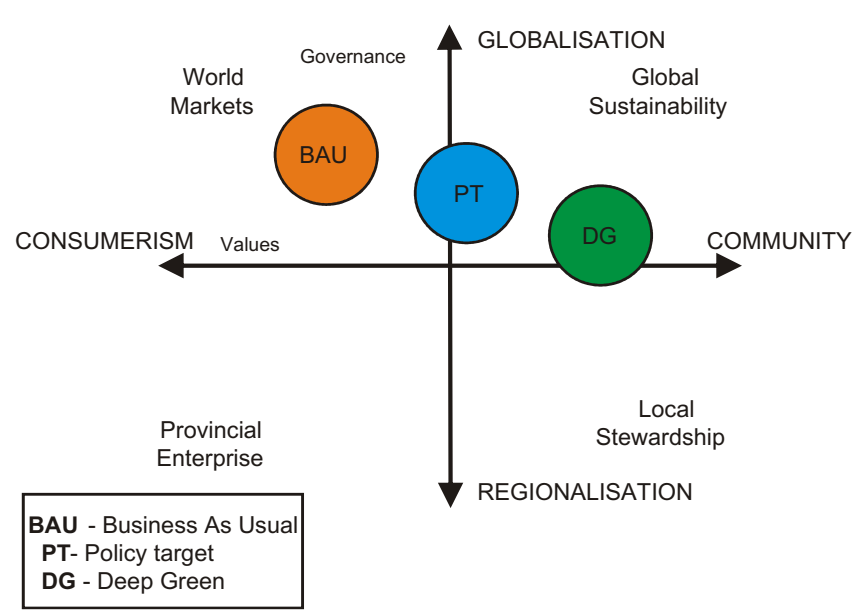

Fig. 1. Different economic scenarios resulting from support to the natural or to the social system, as a function of decision systems (based on Turner et al., 1994). 
the identification of specific disturbance regimes and societal choices of the desired ecosystem services (Brand, 2009).

It is necessary to determine the relationship between ecological resilience and critical natural capital. If we assume that an ecosystem's degree of ecological resilience is inversely related to its degree of threat (Brand, 2009), information on ecological resilience and system efficiency will be required to estimate whether an ecosystem will reach a critical state following environmental stressors (Ulanowicz et al., 2009). That critical state can be regarded as the state of the natural system where the extent of environmental degradation passes a threshold beyond which current levels of social welfare cannot be supported. Hence it is suggested that such an ecological criticality is important for the maintenance of ecosystems services and goods (Jax, 2005) and the sustainable use of natural capital (Brand, 2009).

Natural systems, and their change due to human stressors such as overfishing or pollution, require to be analysed according to their carrying capacity and its loss follow stress. The concept of carrying capacity was originally an ecological construct, defined as the number of individuals of a population an environment can support without significant negative impacts to the given population and its environment (Elliott et al., 2007). This definition does not fully capture the multi-layered processes of human-environment relationships, which have a fluid and non-equilibrium nature, and it may disregard the role of external forces in influencing environmental change (Moore et al., 2009). Because of this, Elliott et al. (2007) emphasise that carrying capacity also should relate to social and economic aspects of ecosystems, i.e. what human activities and anthropogenic change can an ecosystem withstand before adverse change is experienced. Thus the relationship of humans to their environment may be more complex than is the relationship of other species to theirs (Pulselli et al., 2008). Humans can alter the type and degree of their impact on their environment by, for instance, increasing the productivity of land through more intensive farming techniques, leaving a defined local area, or scaling back their consumption. Of course, humans may also irreversibly decrease the productivity of the environment or increase consumption, and/or occupy or transform space. Therefore, the carrying capacity concept requires to be expanded to include socio-economic aspects (MacLeod and Cooper, 2005; Elliott et al., 2007) as although many species can change the carrying capacity of its system (for better or worse), only humans can manipulate it to a much greater extent than other social species (e.g. ants).

The linking between these ecological concepts and the management framework is also relatively recent and the concepts are now being integrated to provide a holistic approach not only to understand, but also to manipulate and manage the environment. Of particular importance to environmental management are ideas relating to the dynamics of ecosystems and the relations between biodiversity and ecosystem function, which have led towards the view that ecosystems are complex adaptive systems, characterised by historical dependency, nonlinear dynamics, threshold effects, multiple basins of attraction, and limited predictability (Folke et al., 2004; Duit and Galaz, 2008; Moore et al., 2009).

How can this panoply of theoretical concepts be applied to marine and estuarine environments? We recognise and emphasise that these have many uses and users, sectorial interests, management and governance regimes (Costanza et al., 1998, 1999; McLusky and Elliott, 2004). For instance, in the restoration, management or sustainable use of a specific ecosystem how can we decide the best possible course of management in a multitude of driving forces which may be conflicting? There is the need for solutions in a multiuse/multiuser/multisectorial system and so we are required to orientate ourselves amongst such complexity. We propose here the use of a conceptual guidance tool, which may act as a kind of compass and might be useful to provide orientation in the process of building and testing management scenarios for dealing with environmental problems. While the ideas here are from the marine coastal and estuarine field, we suggest that they are applicable to other domains.

\section{Building management scenarios towards ecological sustainability}

Environmental problems are intrinsically complex and intimately related to the development of human society. Therefore, possible solutions to environmental problems must always be approached taking into account various viewpoints, expressing the different perceptions of multiple sectors, uses and users, often conflicting (Costanza et al., 1998, 1999). The intrinsic uncertainty involved has often been addressed through economic scenarios (e.g. business as usual, deep green, or unabated capitalism scenarios) (Fig. 1) (Turner et al., 1994, 2003; Turner, 2008), in which the natural or the social systems are favoured differently by different decision systems (Table 1 ).

Scenario analysis therefore is needed as a means of both identifying core questions regarding sustainability (Table 2) and determining priorities and solutions (Kontogianni et al., 2001, 2004; Swart et al., 2004). This illustrates how sustainability science is complex and uncertain. Nevertheless, we may encompass all these different perspectives and apprehensions in the scope of three major drivers:

(a) the search for human well-being and the maintenance of human health and safety;

(b) the endeavour of ecological sustainability and natural environmental well-being;

(c) the tolerance of increasing human population pressures and demand for wealth creation.

Of course, this assumes that our accompanying research should fulfil three aims: of knowledge creation, wealth creation and improvements in the quality of life. In terms of governance, the search for human well-being is often recognised as synonymous with gross domestic product (GDP) or stakeholder benefits, which may eventually be expressed by some kind of tentative metrics (e.g. a well-being index) (Fig. 2). The basic societal (and hence governmental) goal is to maximise economic goods and services while at the same time protecting ecological goods and services (or at least for business not to be prosecuted for harming the latter or for countries, such as in the European Union, not being subject to legal infraction proceedings for failing to meet common laws (directives)).

Sustainability indicators and composite indices are increasingly recognised as valuable tools for policy making and public communication regarding fields such as environment, economy, society or technological improvement (Singh et al., 2009). Despite this, in many cases, sustainability indices applied in policy apparently fail to fulfil fundamental scientific requirements making them rather useless if not misleading with respect to policy advice (Brunner and Starkl, 2004; Böhringer and Jochem, 2007). Despite this, the aim for ecological sustainability is normally associated with the concept of environmental integrity, which can be approached from different theoretical orientations, all involving inherent uncertainties (Fig. 2). There is a variety of tools available to evaluate environmental integrity (e.g. environmental quality indices), although probably none of them are completed suitable (Pinto et al., 2009; Marques et al., 2009). On the other hand, integrated approaches are proving valuable especially where the selected indicators are related to the DPSIR (Drivers, Pressures, State Change, Impacts, Response) approach (McLusky and Elliott, 2004; 
Table 1

Environmental ideologies and sustainability perspectives (Nunneri et al., 2004; Turner et al., 2003; Turner, 2008).

\begin{tabular}{|c|c|c|c|c|}
\hline Very weak sustainability & Weak sustainability & Strong sustainability & Very strong sustainability & \\
\hline $\begin{array}{l}\text { Resource exploitative, growth } \\
\text { maximisation position }\end{array}$ & $\begin{array}{l}\text { Resource conservationist and } \\
\text { managerial position }\end{array}$ & Resource preservationist position & Extreme preservationist position & \\
\hline $\begin{array}{l}\text { Anti-green economy; unfettered } \\
\text { free markets; widening income } \\
\text { inequality not problematic; free- } \\
\text { trade in international markets }\end{array}$ & $\begin{array}{l}\text { Green economy natural capitalism } \\
\text { and new industrial systems green } \\
\text { markets guided by economic } \\
\text { incentive instruments (EIs) (e.g. } \\
\text { pollution charges etc.) in } \\
\text { combination with voluntary } \\
\text { agreements }\end{array}$ & $\begin{array}{l}\text { Deep green economy, steady state } \\
\text { economy regulated by macro- } \\
\text { environmental standards and } \\
\text { supplemented by EIs and } \\
\text { international agreements }\end{array}$ & $\begin{array}{l}\text { Very deep green economy, heavily } \\
\text { regulated to minimise resource- } \\
\text { take; National environmental duty } \\
\text { of care formally regulated; } \\
\text { extensive and binding international } \\
\text { agreements }\end{array}$ & Green labels \\
\hline $\begin{array}{l}\text { Primary economic policy objective, } \\
\text { maximise economic growth } \\
\text { (max gross national product) } \\
\text { (GNP); no formal policy } \\
\text { integration processes }\end{array}$ & $\begin{array}{l}\text { Modified economic growth } \\
\text { (adjusted green accounting to } \\
\text { measure GNP); formal policy } \\
\text { integration and review on } \\
\text { institutional structures of growth } \\
\text { and environmental quality }\end{array}$ & $\begin{array}{l}\text { Zero economic growth; zero } \\
\text { population growth; binding policy } \\
\text { integration }\end{array}$ & $\begin{array}{l}\text { Reduced scale of economy and } \\
\text { population; sustainability } \\
\text { accounting the primary approach }\end{array}$ & $\begin{array}{l}\text { Type of } \\
\text { economy }\end{array}$ \\
\hline $\begin{array}{l}\text { Taken as axiomatic that unfettered } \\
\text { free markets in conjunction with } \\
\text { technical progress will ensure } \\
\text { infinite substitution possibilities } \\
\text { capable of mitigating all local } \\
\text { scarcity limits constraints } \\
\text { (environmental sources and } \\
\text { sinks); voluntary approach to } \\
\text { environmental regulation and } \\
\text { intervention }\end{array}$ & $\begin{array}{l}\text { Decoupling of growth and } \\
\text { environmental quality important } \\
\text { but infinite substitution rejected. } \\
\text { Sustainability Rules: e.g. constant } \\
\text { natural capital rule; use efficiency } \\
\text { and productivity; sustainability } \\
\text { indicators and monitoring }\end{array}$ & $\begin{array}{l}\text { Decoupling plus no increase in } \\
\text { scale; systems perspective - health } \\
\text { of whole ecosystems very } \\
\text { important; over-compliance with } \\
\text { international environmental } \\
\text { agreements; sustainability } \\
\text { assessments and audits }\end{array}$ & $\begin{array}{l}\text { Scale reduction imperative; at the } \\
\text { extreme for some there is a literal } \\
\text { interpretation of the Gaia } \\
\text { hypothesis with moral obligations }\end{array}$ & $\begin{array}{l}\text { Policies and } \\
\text { management } \\
\text { strategies }\end{array}$ \\
\hline $\begin{array}{l}\text { Support for traditional ethical } \\
\text { reasoning; rights and interests } \\
\text { of contemporary individual } \\
\text { humans; instrumental value } \\
\text { (e.g. recognised value to } \\
\text { humans) in nature }\end{array}$ & $\begin{array}{l}\text { Extension of ethical reasoning: } \\
\text { caring for others motive } \\
\text { intergenerational and } \\
\text { intergenerational equity (i.e. } \\
\text { contemporary poor and future } \\
\text { people); instrumental value in } \\
\text { nature }\end{array}$ & $\begin{array}{l}\text { Further extension of ethical } \\
\text { reasoning: interests of the } \\
\text { collective take precedence over } \\
\text { those of individual primary value of } \\
\text { ecosystems and secondary value of } \\
\text { component functions and services }\end{array}$ & $\begin{array}{l}\text { Acceptance of bioethics (i.e. moral } \\
\text { rights/interests conferred on all } \\
\text { non-human species and even the } \\
\text { abiotic parts of the environment: } \\
\text { intrinsic value in nature (i.e. } \\
\text { valuable in its own rights } \\
\text { regardless of human experience) }\end{array}$ & Ethics \\
\hline $\begin{array}{l}\text { Low level of environmental } \\
\text { awareness in the public }\end{array}$ & $\begin{array}{l}\text { Wider public education, } \\
\text { establishment of stakeholder } \\
\text { groups and of e.g. roundtables to } \\
\text { increase inclusion }\end{array}$ & $\begin{array}{l}\text { Strong local/community awareness } \\
\text { and action campaigns }\end{array}$ & $\begin{array}{l}\text { Cultural shifts to the maintenance } \\
\text { of local livehoods and } \\
\text { environmental stewardship }\end{array}$ & $\begin{array}{l}\text { Degree of } \\
\text { public } \\
\text { inclusion }\end{array}$ \\
\hline
\end{tabular}

Table 2

Core questions for sustainability science (modified from Kates et al., 2001; Swart et al., 2004).

1. How can the dynamic interactions between nature and human society - including time-lags due to inertia - be better incorporated into emerging models and conceptualizations that integrate the global systems, human development and sustainability?

2. How are long-term trends and widely varying spatial scales in environment and development, including consumption and population change, reshaping naturesociety interactions in ways relevant to sustainability?

3. What determines the vulnerability and resilience of the nature-society system in particular kinds of places and for particular types of ecosystem and human livehoods?

4. Can scientifically meaningful limits or boundaries be defined that would provide effective warning thresholds beyond which the nature-society systems are at a significantly increased risk of serious degradation?

5. What systems of incentive structures - including markets, rules, norms, and scientific information - can most effectively improve social capacity to guide interactions between nature and society toward more sustainable trajectories?

6. How can today's operational systems for monitoring and reporting on environmental and social conditions be integrated or extended to provide more useful guidance for efforts to achieve sustainability?

7. How can today's relatively independent activities of research, planning, observation, assessment, and decision-support be better integrated into systems for adaptive engagement and societal learning?

8. How can future changes be determined and predicted in a creative, objective, rigorous, and policy-relevant manner that reflects sustainability and incorporates different perspectives?

Aubry and Elliott, 2006; Gray and Elliott, 2009). Additionally, the acknowledgement that much of a nation's economic prosperity depends on ecosystem functioning, and that many natural ecosystems are under threat, has led to the emergence of a new interest in defining, measuring and protecting ecosystem goods and services.

Despite this, there are two main problems when assessing ecosystem services and goods (Heal and Kristrom, 2005): (i) the scale at which certain functions become important is not always the same; and (ii) problems may arise when integrating and aggregating all the temporal and spatial scale information, where interrelations and feedback loops may operate at scales above the level being assessed. As a particular example, in highly dynamic estuarine, coastal and marine areas, economic goods and services at one area depend on the successful functioning elsewhere - e.g. estuarine fish nursery grounds in one area provide the basis for marine commercial stocks in another area (McLusky and Elliott, 2004). In general, scaling rules that attempt to describe the provision and delivery of ecosystem services still require to be quantified and defined, especially for open and dynamic systems (see also Limburg et al., 2002).

Of course, human population pressure is increasing directly as a result of population growth and the resultant increasing resource consumption and pollution related to the pursuit of satisfying 


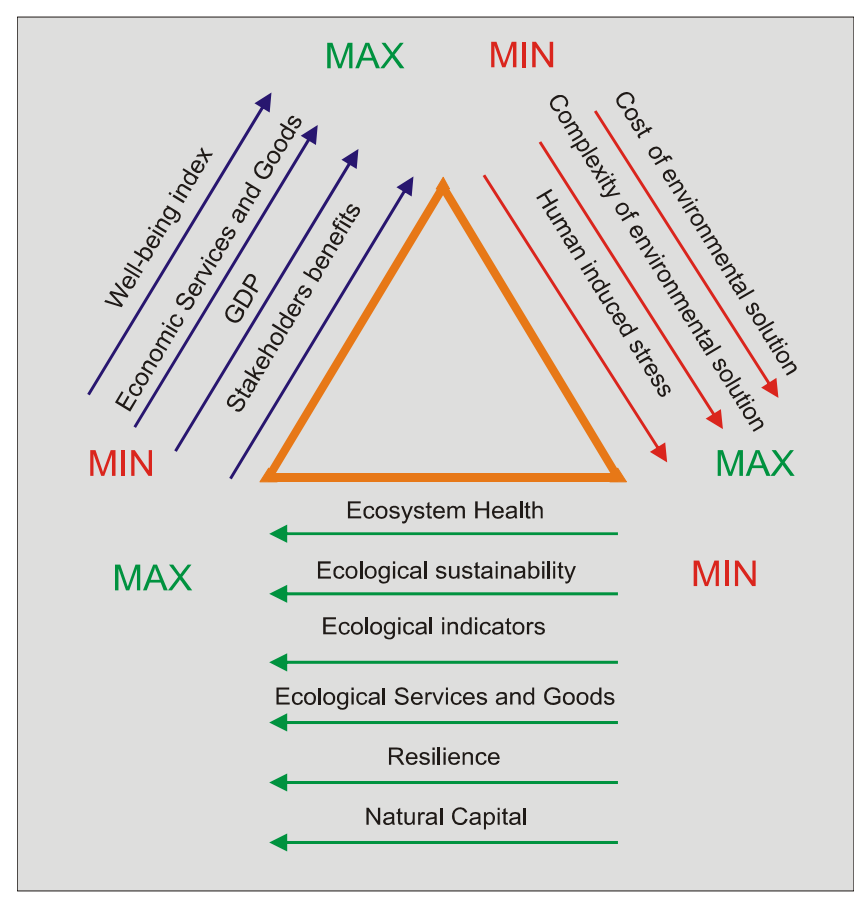

Fig. 2. The ecological sustainability trigon (EST) illustrating the expected trends and relationships between variables assumed to be correlated with ecological sustainability, human well-being and population size/pressure. The bottom and left-hand axes of the EST indicate how governance and societal systems must be linked to environmental management, while the right-hand axis illustrates how increasing human pressures imply consequences on the other two axes. Green good; red - bad; yellow - acceptable state. (For interpretation of the references to colour in this figure legend, the reader is referred to the web version of this article.)

increasing human needs. Such pressures then gradually increase the complexity and difficulty of attaining the solutions to environmental problems together with their inherent costs (Fig. 2). Since it is likely that the needs of future generations will be the same as ours in terms of quantity and quality, we may expect that, compared to today, two changes may happen: (i) overall carrying capacity will decrease, and (ii) the number of options (the number of different resources and our ability to exploit them) will decrease. Shifts in regimes in relation to resilience and the functional roles of biological diversity in both terrestrial and aquatic ecosystems are likely to occur (Folke et al., 2004), and therefore future generations will have to adapt their ways accordingly to manage ecosystems, and that adaptation may have to be rapid.

Given international agreements adopted by most countries, for example the Convention on Biological Diversity, and national laws passed, we can assume that ecological sustainability constitutes a major goal for human society. It would be conceptually possible to maximise ecological sustainability and stakeholder benefits, but only if there is a very low population size and pressure. Also, it would be possible to maximise ecological sustainability and population size but this would entail a much lower standard of human well-being. Of course, at least in the short term, we could maximise stakeholders' benefits and the size of population and its pressure, but only if we abandon the goal of ecological sustainability. However, in the "game of possibles" there is no conceivable scenario that allows maximising the three simultaneously, although a trade-off between aiming for ecological sustainability, the search for human well-being and the increasing human population pressure would be conceptually possible - we will call this the 'ecological sustainability trigon' (EST) (Fig. 3). The bottom and left-hand axes of the EST indicate how governance and societal systems must be linked to environmental management in order to increase the

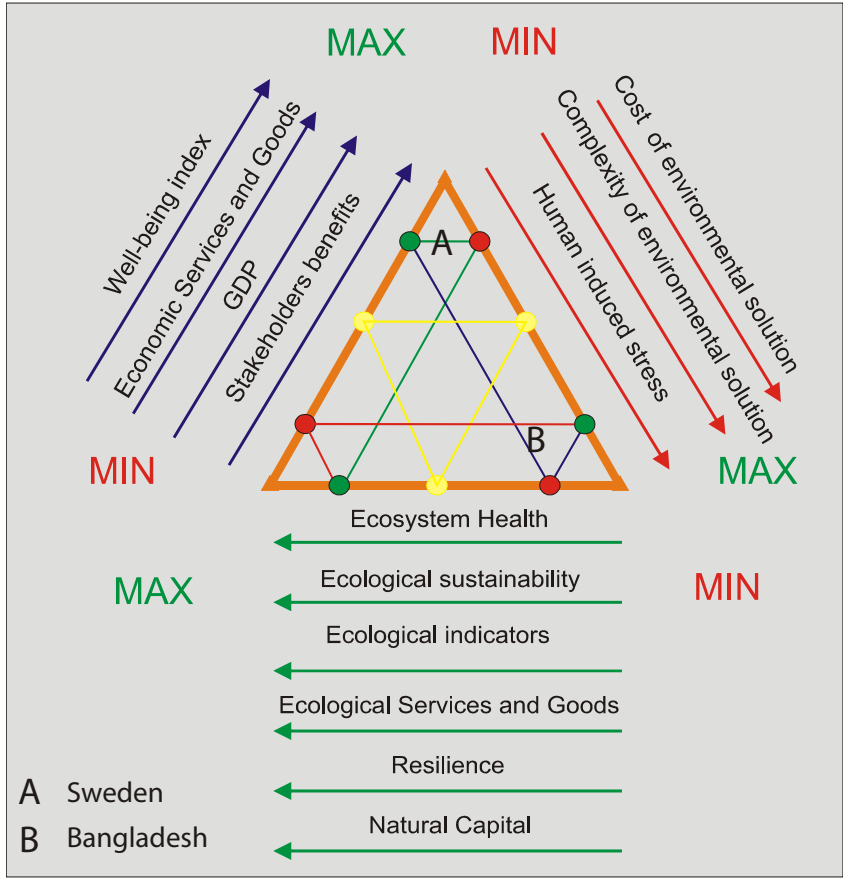

Fig. 3. Proposed use of the ecological sustainability trigon in building management scenarios: analysis of the expected variations and relationships of different variables correlated with ecological sustainability, human well-being and population size/pressure (see legend of Fig. 2 for details).

chances of moving both from MIN in the direction of MAX, which is our goal. The right-hand axis illustrates how increasing human pressures from MIN towards MAX have inevitable consequences on the other two axes, which perhaps may be adverse.

Therefore, EST allows an immediate and intuitive integrated view of possible implications of management decisions, even when processes behind relationships are not fully understood. Moreover, any one case study should correspond to a position on the EST. In Fig. 3, Sweden for instance - a small, rich population, with good coastal ecosystem governance, few environmental problems and a high capability to tackle those problems - would be superimposed approximately at position A. Bangladesh, including the Sunderbands mangrove area, has a high population and high human stress, poor funding and poor governance systems to effect a solution, large pressures on ecosystems, and solutions not ecologically sensitive, which affects its population well-being; this would be placed at position $B$.

These two classic examples at the country scale illustrate how the EST may help a decision maker to (a) identify the links between drivers and (b) clarify/decide which direction management should take in order to bring any system closer to an optimal position in the trigon. Most importantly, we argue that the trigon can in principle be used as a conceptual guidance tool independently from the scale of the management scenario we may want to build.

It is of course necessary to realise that there are things which can be managed and other things which cannot and that choices have to be made, and so the trigon may constitute an intuitive tool with that regard. For instance, Bangladesh cannot alter its population size and human pressure, although it could improve its governance and environmental management. Similarly, in environmental management there are some pressures which can be managed at a local scale, for example the discharge of pointsource polluting materials, but others which cannot. Climate change is an example of the latter whereby local managers are not managing climate change but merely responding to its 

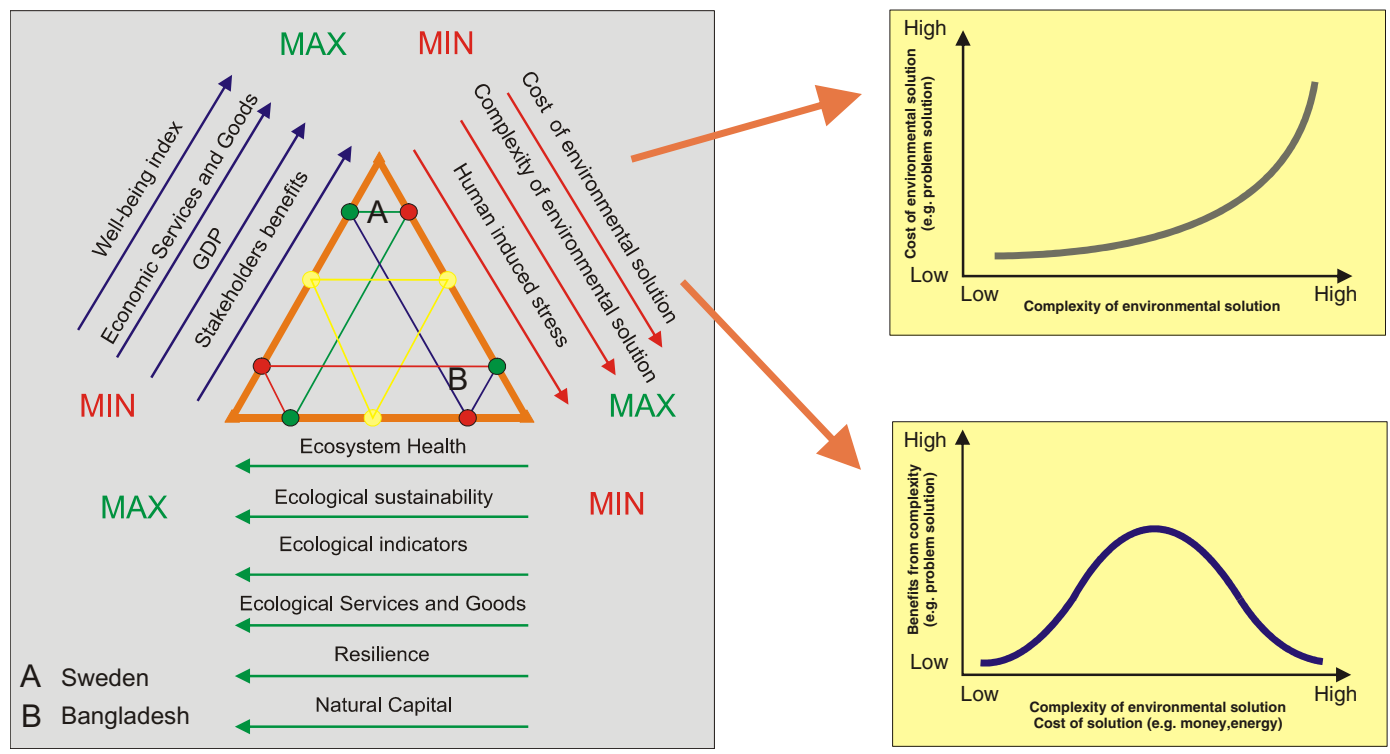

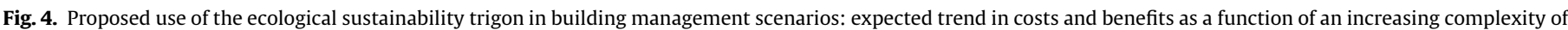
environmental problems solutions (see legend of Fig. 2 for details).

consequences. For this reason we talk of climate change as an 'exogenic unmanaged pressure'.

In general, it must be assumed that reconciling the difficulties in jointly achieving the three drivers (ecological sustainability, human well-being and human population/size pressure) cannot simply rely on solving the increasing complexity of environmental problems. In fact, the benefits from achieving the harmonisation of these complex solutions will not increase linearly as a function of that complexity, since the inherent costs (energy and money) will most probably become not sustainable in the long term (Fig. 4).

\section{What might be the advantages of the ecological sustainability trigon (EST)?}

The EST as proposed here is a tentative and intuitive view which of course requires further testing and debate. In building management scenarios, the number of variables that must be taken into account is extremely high and the uncertainties regarding their relationships and trends may also be high. In fact, the core problem is the sustainability of interactions between economic and ecological systems, which involves issues that are fundamentally crossscale, transcultural, and transdisciplinary, and calls for innovative approaches to research, to policy and to the building of social institutions (Costanza et al., 1998, 1999). The use of the ecological sustainability trigon as a conceptual framework may be valuable as a tool to provide orientation (a kind of compass) and in building predictive management scenarios ("In which direction do we want to go?" "How do we get there?"), instead of the more conservative forecast scenarios ("Where are we going to?"). In other words, scenarios built to address not only adaptations to current conditions and actions in the short term, but also how to achieve transformations toward more sustainable development pathways (Folke, 2006). Examples of different variables with which the trends are likely to be correlated can be organised along the three sides of the triangle, with their expected trends varying from maximum (MAX) to minimum (MIN) (Figs. 2-4). Many other variables could of course be included.

The applicability of governance theory, which considers the legal and administration of policy implementation, for instance, implies developing hypothesis about how different governance types can be expected to handle processes of change, which are characterised by nonlinear dynamics, threshold effects, cascades, and limited predictability (Duit and Galaz, 2008). Also, linkages between ecological science and environmental policy are poor, which have been attributed to scientific uncertainty and a lack of consensus amongst scientists, both jeopardizing the transfer of science into management (Moore et al., 2009). The use of EST as an orientation tool may prove useful in testing governance hypothesis, as well as to analyse and integrate, at least approximately (especially as correlations are far from being linear), the expected variations and relationships between different variables correlated with ecological sustainability, human well-being and population size/ pressure. This in turn may prove to be valuable in intuitively clarifying, namely for a decision maker, what is compliant and what is not compliant with the goal of sustainability, as well as in finding the possible safety margin in the "game of possibles".

The EST approach has the advantage of being able to address and measure all components with a same species-specific currency, i.e. the human society view and, at the same time, to describe our behaviour, energetics (economy) and dynamics with the same tool used for all other ecosystem components, i.e. ecological theory. Of course, the incorporation of our behaviour, energetics and dynamics into an ecosystem integrity framework poses key challenges for the science of ecology. In fact, it will require measures of ecological status from ecosystem organisation and functioning rather than from pressures and vulnerability. However, the EST approach makes explicit the evaluation criteria for environmental management scenarios, i.e. scales should match (time and space), interactions should match (relationships), and rates should match (biophysical limits). In this sense, we suggest that the EST appears to be promising for gap analysis (information concerning knowledge lacunae), as well as to address new research questions.

\section{References}

Aubry, A., Elliott, M., 2006. The use of environmental integrative indicators to assess seabed disturbance in estuaries and coasts: application to the Humber Estuary. Marine Pollution Bulletin 53 (1-4), 175-185.

Böhringer, C., Jochem, P.E.P., 2007. Measuring the immeasurable-a survey of sustainability indices. Ecological Economics 63, 1-8. 
Brand, F., 2009. Critical natural capital revisited: ecological Resilience and sustainable development. Ecological Economics 68, 605-612.

Brundtland, G.H. (Chair), 1987. Report on the World Commission on Environment and Development: Our common future. Transmitted to the General Assembly as an Annex to document A/42/427 - Development and International Cooperation: Environment. UN Documents: Gathering a Body of Global Agreements; <http://www.un-documents.net/wcedocf.htm>.

Brunner, N., Starkl, M., 2004. Decision aid systems for evaluating sustainability: a critical survey. Environmental Impact Assessment Review 24 (4), 441-469.

Bunce, M., Rodwell, L.D., Gibb, R., Mee, L., 2008. Shifting baselines in fishers' perceptions of island reef fishery degradation. Ocean and Coastal Management 51 (4), 285-302.

Carpenter, S.R., Westley, F., Turner, M.G., 2005. Surrogates for resilience of socialecological systems. Ecosystems 8, 941-944.

Costanza, R., Andrade, F., Antunes, P., Van den Belt, M., Boersma, D., Boesch, D.F., Catarino, F., Hanna, S., Limburg, K., Low, B., Molitor, M., Pereira, J.G., Rayner, S., Santos, R., Wilson, J., Young, M., 1998. Principles for sustainable governance of the oceans. Science 281, 198-199.

Costanza, R., Andrade, F., Antunes, P., Van den Belt, M., Boesch, D., Boersma, D., Catarino, F., Hanna, S., Limburg, K., Low, B., Molitor, M., Pereira, J.G., Rayner, S., Santos, R., Wilson, J., Young, M., 1999. Ecological economics and sustainable governance of the oceans. Ecological Economics 31, 171-187.

De Groot, R., Van der Perk, J., Chiesura, A., van Vliet, A., 2003. Importance and threat as determining factors for criticality of natural capital. Ecological Economics 44, 187-204.

Duit, A., Galaz, V., 2008. Governance and complexity - emerging issues for governance theory. Governance - An International Journal of Policy and Administration 21 (3), 311-335.

Ekins, P., Simon, S., Deutsch, L., Folke, C., De Groot, R., 2003. A framework for the practical application of the concepts of critical natural capital and strong sustainability. Ecological Economics 44 (2-3), 165-185.

Elliott, M., Boyes, S.J., Burdon, D., 2006. Integrated marine management and administration for an island state-the case for a new Marine Agency for the UK. Marine Pollution Bulletin 52 (5), 469-474.

Elliott, M., Burdon, D., Hemingway, K.L., Apitz, S., 2007. Estuarine, coastal and marine ecosystem restoration: confusing management and science-a revision of concepts. Estuarine, Coastal and Shelf Science 74, 349-366.

Folke, C., 2006. Resilience. the emergence of a perspective for social-ecological systems analyses. Global Environmental Change 16, 253-267.

Folke, C., Carpenter, S., Walker, B., Scheffer, M., Elmqvist, T., Gunderson, L., Holling, C.S., 2004. Regime shifts, resilience, and biodiversity in ecosystem management. Annual Review of Ecology, Evolution and Systematics 35, 557-581.

Gray, J.S., Elliott, M., 2009. Ecology of Marine Sediments: Science to Management Oxford University Press, Oxford.

Grimm, V., Wissel, C., 1997. Babel, or the ecological stability discussions: an inventory and analysis of terminology and a guide for avoiding confusion. Oeacologia 109, 323-334.

Gunderson, L.H., Holling, C.S. (Eds.), 2002. Panarchy: Understanding Transformations in Human and Natural Systems. Island Press, Washington, DC.

Heal, G., Kristrom, B., 2005. National income and the environment. In: Maler, K.G., Jeffrey, V. (Eds.), Handbook of Environmental Economics, vol. 3. Elsevier (Chapter 22)

Holling, C.S., 1996. Engineering resilience versus ecological resilience. In: Schulze, P.C. (Ed.), Engineering within Ecological Constraints. National Academy Press, Washington, DC, pp. 31-44.

Hughes, T.P., Bellwood, D.R., Folke, C., Steneck, R.S., Wilson, J., 2005. New paradigms for supporting the resilience of marine ecosystems. Trends in Ecology and Evolution 20 (7), 380-386.

Jax, K., 2005. Function and "functioning" in ecology. What does it means? Oikos 111, 641-648.

Kates, R.W., Clark, W.C., Corell, R., Michael Hall, J., Jaeger, C.C., Lowe, I., McCarthy, J.J., Schellnhuber, H.J., Bolin, B., Dickson, N.M., Faucheux, S., Gallopin, G.C., Grübler, A., Huntley, B., Jäger, J., Jodha, N.S., Kasperson, R.E., Mabogunje, A., Matson, P., Mooney, H., Moore III, B., O'Riordan, T., Svedin, U., 2001. Environment and development: sustainability science. Science 292 (5517), 641-642.
Kay, J.J., Boyle, M., Regier, H.A., Francis, G., 1999. An ecosystem approach for sustainability: addressing the challenge of complexity. Futures 31, 721-742.

Kontogianni, A., Skourtos, M.S., Langford, I.H., Bateman, I.J., Georgiou, S., 2001. Integrating stakeholder analysis in non-market valuation of environmental assets. Ecological Economics 37 (1), 123-138.

Kontogianni, A., Skourtos, M.S., Langford, I.H., Bateman, I.J., Georgiou, S., 2004. Integrating stakeholder analysis in non-market valuation of environmental assets. In: Turner, R.K., Georgiou, S., Bateman, I.J. (Eds.), Environmental Decision Making and Risk Management: Selected Essays by Ian H. Langford. Edward Elgar Publishing, Cheltenham, pp. 246-263.

Lebel, L., Anderies, J.M., Campbell, B., Folke, C., Hatfield-Dodds, S., Hughes, T.P., Wilson, J., 2006. Governance and the capacity to manage resilience in regional social-ecological systems. Ecology and Society 11 (1), 19.

Levin, S.A., Lubchenco, J., 2008. Resilience, robustness, and marine ecosystem-based management. Bioscience 58 (1), 27-32.

Limburg, K.E., O’Neill, R.V., Costanza, R., Farber, S., 2002. Complex systems and valuation. Ecological Economics 41, 409-420.

MacLeod, M., Cooper, J.A.G., 2005. Carrying capacity in coastal areas. In: Schwartz, M. (Ed.), Encyclopedia of Coastal Science. Springer, Heidelberg, p. 226.

Marques, J.C., Salas, F., Patrício, J., Neto, J., Teixeira, H., 2009. Ecological Indicators for Coastal and Estuarine Environmental Assessment - A User Guide. Wit Press. 208 pp.

McLusky, D.S., Elliott, M., 2004. The estuarine ecosystem; ecology, threats and management, third ed. OUP, Oxford. p. 216.

Mee, L.D., Jefferson, R.L., Laffoley, Dd'A, Elliott, M., 2008. How good is good? Human values and Europe's proposed Marine Strategy Directive. Marine Pollution Bulletin 56, 187-204.

Moore, S.A., Wallington, T.J., Hobbs, R.J., Ehrlich, P.R., Holling, C.S., Levin, S., Lindenmayer, D., Pahl-Wostl, C., Possingham, H., Turner, M.G., Westoby, M., 2009. Diversity in current ecological thinking: implications for environmental management. Environmental management 43, 17-27.

Nunneri, C., Turner, K., Cislak, A., Kannen, A., Klein, R., Ledoux, L., Marquenie, J., Mee, J., Moncheva, S., Nicholls, R., Salomons, W., Sardá, E., Stive, M., Vellinga, T., 2004. Integrated assessment and future scenarios for the coast. In: Salomons, W., Vermaat, J., Turner, K. (Eds.), Managing European Coasts: Past, Present and Future. Springer Press, Berlin, pp. 271-289.

Ojeda-Martínez, C., Casalduero, Francisca Giménez, Bayle-Sempere, Just T., Cebrián, Carmen Barbera, Valle, Carlos, Sanchez-Lizaso, Jose Luis, Forcada, Aitor, Sanchez-Jerez, Pablo, Martín-Sosa, Pablo, Falcón, Jesús M., Salas, Fuensanta, Graziano, Mariagrazia, Chemello, Renato, Stobart, Ben, Cartagena, Pedro, PérezRuzafa, Angel, Vandeperre, Fréderic, Rochel, Elisabeth, Planes, Serge, Brito, Alberto, 2009. A conceptual framework for the integral management of marine protected areas. Ocean and Coastal Management 52 (2), 89-101.

Pinto, R., Patrício, J., Baeta, A., Fath, B.D., Neto, J.M., Marques, J.C., 2009. Review and evaluation of estuarine biotic indices to assess benthic condition. Ecological Indicators 9 (1), 1-25.

Pulselli, F.N., Bastianoni, S., Marchettini, N., Tiezzi, E., 2008. Road to Sustainability, GDP and Future Generations. WIT Press, Southampton. p. 197.

Singh, R.K., Murty, H.R., Gupta, S.K., Dikshit, A.K., 2009. An overview of sustainability assessment methodologies. Ecological Indicators 9, 189-212.

Swart, R., Raskin, P., Robinson, J., 2004. The problem of the future: sustainability science and scenario analysis. Global Environmental Change 14, 137-146.

Turner, R.K., Pearce, D., Bateman, I., 1994. Environmental Economics: an Elementary Introduction. Harvester Wheatsheaf, London. p. 328

Turner, R.K., Georgiou, S., Brouwer, R., Bateman, I.J., Langford, I.H., 2003. Towards an integrated environmental assessment for wetland and catchment management. Geographical Journal 169 (2), 99-116.

Turner, G.M., 2008. A comparison of the limits to growth with 30 years of reality. Global Environmental Change 18, 397-411.

Walker, B., Hollin, C.S., Carpenter, S.R., Kinzig, A., 2004. Resilience, adaptability and transformability in social-ecological systems. Ecology and Society 9 (2), 5.

Ulanowicz, R.E., Goerner, S.J., Lietaer, B., Gomez, R., 2009. Quantifying sustainability: resilience, efficiency and the return of information theory. Ecological Complexity 6, 27-36. 